\title{
Short Term Ration Restriction and Re-Alimentation: Effect on Compensatory Growth, Body Composition and Insulin Like Growth Factor Gene Expression in Cyprinus carpio
}

\author{
Sanjit Debbarma ${ }^{1}$, V. K. Tiwari $^{1}$, A.K. Reddy ${ }^{1}$, A. Pavan Kumar ${ }^{1}$, \\ Babitha Rani A.M ${ }^{1, *}$ \\ ${ }^{1}$ Central Institute of Fisheries Education, Off Yari Road, Panch Marg, Versova, Andheri (W), Mumbai-400061.
}

\section{Article History}

Received 27 February 2018

Accepted 10 Deecember 2019

First Online 16 December 2019

\section{Corresponding Author}

Tel.:

E-mail: babitarani@cife.edu.in

\section{Keywords}

Cyprinus carpio

Body Weight

Body Composition

IGF-I and IGF2a Gene Expression

\begin{abstract}
Advanced fry of Cyprinus carpio (mean weight $1.73 \pm 0.02 \mathrm{~g}$ ) were fed at $10 \%, 25 \%, 50 \%$ and $75 \%$ of satiation as different treatment groups and one control group ( 6 weeks) for first phase (restriction feeding) and a second phase ( 8 weeks) of satiation feeding for all the treatments. At the end of first phase, there was significant difference in mean weight among the treatment groups $(P<0.05)$ but, after second phase ( 8 weeks), treatment group fed at $75 \%$ of satiation obtained significantly higher body weight than control, while $50 \%$ satiation fed group obtained similar weight as of control. FCR was found to be better at moderately restricted fed group ( $50 \%$ and $75 \%$ satiation). Crude protein and crude lipid content decreased in severely restricted groups (10\% and $25 \%$ of satiation fed), compared to others after 14 weeks. IGF-I and IGF-2a gene expression in the liver was observed as down regulated during ration restriction and up regulated after re alimentation. However, after re-alimentation for 8 weeks, IGF-2a gene expression was recorded to be increasing and was higher than control. The study concludes that moderate levels of ration restriction ( $50 \%$ to $75 \%$ of satiation levels) is sufficient for effective growth and feed utilization.
\end{abstract}

\section{Introduction}

Feeding costs in aquaculture typically accounts for $60 \%$ of production cost. Different means of cost effective feeding along with water quality maintenance through reduced organic load to the system is the major challenge in modern aquaculture. One of the simplest and widely adopted practices in aquaculture is restricting the feed for a short period of time for cultured animals. The amount of feed given to fish is drastically reduced for days to months before the fish are re-fed to satiation levels (Robb, 2008; Jobling, 2012). By imposing ration restrictions, it will not only reduce the operating costs, but also reduce the organic load in to the culture system (Abdel-Hakim, Abo State, Al-Azab and El-Kholy, 2009; Jobling, 2012).

Fasting or ration restriction may be applied in commercial fish farming to induce growth compensation. Imposing ration restrictions naturally suppress fish growth for the entire period of restricted feeding. But once the restrictions are over and the fishes are re-fed at satiation levels, they have a remarkable ability to bounce back via compensatory and/or catchup growth responses (Hayward, Noltie and Wang, 1997; Ali, Nicieza and Wootton, 2003; Weirich, Groat, Reigh, Chesney and Malone, 2006; Jobling, 2009). The degree of compensatory growth depends on species, duration of starvation, levels of food deprivation, different body 
size and different experimental protocols (Ali et al., 2003; Foss, et al., 2009).

Fish growth is controlled by the growth hormone (GH) / insulin-like growth factor-I (IGF-I) axis and muscle growth rate which depends on feeding regimes or environmental conditions (Johnston, 2001b; Wood, Duan, and Bern, 2005). Under anabolic conditions growth hormone stimulates the production and subsequent release of insulin-like growth factor-I into the circulation and IGF-I act on target tissues to proliferate and differentiate and will lead to body growth of the fishes (Wood et al., 2005). Growth hormone also act directly on target tissues such as skeletal muscle to stimulate IGF-I production to promote tissue growth. It is widely accepted that fasting or reduced feeding decreases concentrations of IGF-I in channel catfish (Ictalurus punctatus) and other teleosts (Peterson and Waldbieser, 2009), whereas the effects of nutritional status on IGF-II are less defined. The purpose of the present study was to investigate the influence of different degree of restricted feeding on compensatory growth, body composition, IGF-I and IGF-2a gene expression in Cyprinus carpio (Linnaeus, 1758).

\section{Materials and Methods}

\section{Animals and Experimental Design}

The experiment was carried out at the wet laboratory of Aquaculture division, CIFE, Mumbai. The advanced fry of Cyprinus carpio $(1.55 \pm 0.03 \mathrm{~g})$, were procured from Maa Tara packing centre, Bijoynagar, Naihati, 24-Pgs (North), West Bengal, India and were acclimatized to the experimental conditions for one month. Experiment was carried out in two phases; first phase ( 6 weeks) of ration restriction at various ration levels and second phase ( 8 weeks) of feeding up to satiation levels.
Fishes $(n=20)$ were stocked in 15 circular tanks $(300 \mathrm{~L})$ and were aerated well. The treatment groups T1, $\mathrm{T} 2, \mathrm{~T} 3$ and T4 were fed at the rate of $10 \%, 25 \%, 50 \%$ and $75 \%$, respectively of the satiation level of controls respectively for the first 6 weeks and the fishes of all the treatment groups were fed to the satiation level for the next 8 weeks. The control fishes were fed up to the satiation level daily and was offered in two equal portions once at morning $(0100 \mathrm{~h})$ and another at evening $(1700 \mathrm{~h})$ to ensure optimum feed intake and to minimize wastage of feed. The control group fishes were fed @ 5\% body weight and later on they were fed at the level of apparent satiation. The amount of feed given to various treatment groups was adjusted by daily evaluation of satiation feeding for control.

The uneaten feed was collected after $60 \mathrm{~min}$ of feeding and then oven-dried at $70^{\circ} \mathrm{C}$. The amount of uneaten feed was reduced during calculating FCR. The diet was formulated with $35 \%$ crude protein containing fish meal $(27.65 \%)$, soybean meal $(15.75 \%)$, groundnut oil cake $(17 \%)$, rice powder $(9 \%)$, wheat flour $(16 \%)$, corn flour (8\%), vegetable oil (5\%), vitamin mineral premix (1\%) and BHT (0.6\%) (Table 1).

The water quality parameters like temperature (23.4- $\left.28.1^{\circ} \mathrm{C}\right)$, pH (7.6-8.1), dissolved Oxygen (6.6$\left.7.3 \mathrm{mgL}^{-1}\right)$, alkalinity $\left(96-120 \mathrm{mgL}^{-1}\right)$, Ammonia-Nitrogen (0.04-0.09 $\left.\mathrm{mgL}^{-1}\right)$, Nitrite- Nitrogen (0.002-0.005 $\mathrm{mgL}^{-1}$ ) were recorded at biweekly intervals following the standard methods (APHA,1998). The water quality was maintained by regular siphoning of faecal matter, water exchange and aeration.

\section{Sampling and Analysis}

Sampling was carried out at bi-weekly intervals to assess the body weight of the fishes. Fishes were starved overnight and weighed in an electronic balance. Five fishes were taken from each tank for analysing the

Table 1. Ingredient and proximate composition of the experimental diet

\begin{tabular}{lc}
\hline Ingredient & \% Inclusion \\
\hline Fish meal & $27.65 \%$ \\
Soybean meal & $15.75 \%$ \\
Groundnut oil cake & $17 \%$ \\
Rice powder & $9 \%$ \\
Wheat flour & $16 \%$ \\
Corn flour & $8 \%$ \\
Vegetable oil & $5 \%$ \\
Vitamin mineral premix & $1 \%$ \\
BHT & $0.6 \%$ \\
Proximate composition $\%$ & \\
\hline Moisture & $9.88 \%$ \\
Protein & $34.27 \%$ \\
Lipid & $7.70 \%$ \\
Ash & $9.50 \%$ \\
\hline
\end{tabular}

*Diet was formulated using software Win Feed Version 2.8. 
growth of fishes. The growth performance was measured as final body weight and Feed conversion ratio (FCR): feed given (dw)/weight gain (ww) where, dw- dry weight, ww- wet weight. FCR was analysed only after second phase of experiment. IGF-I and IGF2a gene expression were measured after both the phases of the experiment.

\section{Body Composition}

At the end of second phase (14 weeks), three fishes were collected randomly from each of the experimental tank and the biomass of the fishes was noted down. Samples were stored at $-20^{\circ} \mathrm{C}$ and protein, lipid and ash contents were measured using prescribed method (AOAC, 1995). Moisture content was analysed by drying the samples to constant weight at $100-105^{\circ} \mathrm{C}$, crude protein (CP) by Kjeltec semi-automatic system (2200 Kjeltec Auto Distillation, Foss Tecator, Sweden) and ether extract by Soxhlet Apparatus using petroleum ether (Boiling point $40-60^{\circ} \mathrm{C}$ ) as solvent. Total carbohydrate was calculated by difference as 100 (moisture + Crude protein + Lipid + ash).

\section{Quantification of IGF-I and IGF2a gene expression by qRT- PCR}

Two fishes were randomly taken from each experiment after completion of each phase of the experiment (first phase 6 weeks and second phase 8 weeks) and were anesthetized using clove oil. Liver tissue was collected from these fishes and preserved in Qiagen's RNA later RNA stabilizing reagent $(10 \mu \mathrm{l} 100 \mathrm{mg}$ tissue ${ }^{-1}$ ) and stored under $-80^{\circ} \mathrm{C}$ until RNA extraction.

\section{RNA Isolation and Processing}

Total RNA was isolated using Trizol $^{\circledR}$ method (Sambrook and Russell, 2001). RNA was quantified by using Nanodrop (Thermo scientific, USA) with DEPC treated water or nuclease free water as blank and measured concentration in $\mathrm{ng} \mu \mathrm{l}^{-1}$. The purity of RNA was also checked at $1 \%$ agarose gel.

Total RNA was purified by treating with DNAse enzyme. The purification reaction mixture was prepared for a volume of $10 \mu \mathrm{l}$ by adding 1ug of total RNA, 1ug of buffer (10X), 1ul DNAse enzyme and nuclease free water. The reaction mixture was incubated at $37^{\circ} \mathrm{C}$ for $30 \mathrm{~min}$ followed by addition of $2 \mu \mathrm{l}$ of $20 \mathrm{mM}$ EDTA. Later the reaction was terminated by incubating at $65^{\circ} \mathrm{C}$ for 10 min. The purified total RNA was used for the subsequent cDNA synthesis.

\section{Complementary DNA (cDNA) Synthesis}

The mRNA from DNAse treated total RNA pool was reverse transcribed to first strand cDNA using Maxima First Strand CDNA synthesis Kit RT-qPCR (Thermo Scientific, USA). Briefly, $1 \mu \mathrm{g}$ of total RNA, $2 \mu \mathrm{l} 5 \mathrm{x}$ reaction mix $(2 \mu \mathrm{l})$ and about $1 \mu \mathrm{l}$ maxima enzyme mix were taken in $0.5 \mathrm{ml}$ microfuge tube and total reaction mixture volume was made up to $10 \mu \mathrm{l}$ with nuclease free water. The tube was incubated in PCR machine for $10 \mathrm{~min}$ at $25^{\circ} \mathrm{C}$ followed by $15 \mathrm{~min}$ at $50^{\circ} \mathrm{C}$. The reaction was terminated at $85^{\circ} \mathrm{C}$ for $5 \mathrm{~min}$.

Specific primers were designed for Insulin like Growth Factor-I (IGF-I), Insulin like Growth Factor 2a (IGF2a) and one housekeeping gene (GAPDH) for real Time PCR (Table 2).

\section{Real Time PCR}

Real Time PCR amplifications were conducted in Roche Light Cycler Real Time PCR detection system (Roche system). The $12.5 \mu \mathrm{l}$ of reaction mixture volume consist of $12.5 \mu$ l of Maxima ${ }^{\mathrm{TM}}$ SYBR Green qPCR Master mix (Thermo scientific, USA), $0.5 \mu$ l of $(0.3 \mu \mathrm{M})$ each gene specific primer and $2 \mu \mathrm{l}$ (20ng) of cDNA. The default thermal profile was used for amplification and it consisted of initial denaturation at 95 oc for $10 \mathrm{~min}$ followed by 40 cycles of denaturation at 95 ㅇ for $15 \mathrm{sec}$, annealing and extension at 60 $\mathrm{C}$ for $1 \mathrm{~min}$. Melting curve analysis of amplification products were performed at the end of each PCR reaction to confirm that only one PCR product was amplified and detected. Comparative $C_{T}$ method was used to estimate the relative expression of mRNA. The $\Delta C_{T}$ was calculated by subtracting $C_{T}$ value of internal control from target gene and then mean $\Delta C_{T}$ was calculated from this normalized $\Delta C_{T}$ value. $\Delta \Delta C_{T}$ was calculated with respect to control by subtracting mean $\mathrm{C}_{\mathrm{T}}$ of control treatment from mean $\Delta \mathrm{C}_{\mathrm{T}}$ of target gene. Fold change at various ration restriction and realimentation periods were calculated by $2^{-\Delta \Delta c_{T}}$. The house keeping gene, glyceraldehyde 3- phosphate dehydrogenase was utilized as an internal control for normalization (Su. et al., 2008).

\section{Statistical Analysis}

Difference between feeding treatments in terms of mean weight, FCR and IGF-I and IGF2a gene expression were tested with one-way analysis of variance (ANOVA). Significant differences between treatment means $(P<0.05)$ were determined by Duncan's multiple range test (Duncan1955) using PROC GLM procedure (SAS 9.3)

\section{Results}

Initial mean weight of the fish did not vary significantly among the treatment groups (Table 3 ). At the end of first phase of the experiment, highest mean weight was observed in control followed by T4 (75\% satiation fed). At the end of second phase, treatment T4 (75\% satiation fed) attained significantly higher weight gain than control group and T3 (50\% satiation fed group) obtained significantly similar weight as of control $(P<0.05)$.

The better FCR was found in T3 (50\% satiation fed) compared to other treatment groups but severely ration 
Table 2. Primers used in the gene expression studies

\begin{tabular}{|c|c|c|c|c|c|}
\hline Gene & Primers & Primer sequence & $\begin{array}{c}\text { Annealing } \\
\text { Temperature }(\stackrel{\circ}{ } \mathrm{C})\end{array}$ & $\begin{array}{l}\text { Amplicon } \\
\text { size }\end{array}$ & $\begin{array}{c}\text { Gene bank } \\
\text { accession no }\end{array}$ \\
\hline & IGFI-F & AACGGCACACAGACAGTCCCAG & 58.6 & 157 & D83271.1 \\
\hline \multirow[t]{2}{*}{ IGF-I } & IGFI-R & TCTCTCTCAGCCATTCGCCCTAC & 58.5 & 157 & D83271.1 \\
\hline & IGF2a-F & ATCAAACAGCCGCCGTCCTCAG & 62.1 & 109 & HM641129.1 \\
\hline \multirow[t]{2}{*}{ IGF2a } & IGF2a-R & TCGCTCGGACTTCACAGGCTTTG & 62.3 & 109 & HM641129.1 \\
\hline & GAPDH-F & TGATTCATTCTGCGTACCTCTGGG & 59 & 126 & $\mathrm{JX} 244278.1$ \\
\hline GAPDH & GAPDH-R & CAGCCGCAGCCTTAACCACTTTC & 60.9 & 126 & $J X 244278.1$ \\
\hline
\end{tabular}

Table 3. Effect of ration restriction ( $6^{\text {th }}$ week) and re-alimentation ( $8^{\text {th }}$ week) on body weight of $C$. Carpio after restricted feeding phase (first phase) and satiation feeding phase (second phase)

\begin{tabular}{|c|c|c|c|c|c|}
\hline \multirow[t]{2}{*}{ Parameters } & \multirow[t]{2}{*}{ Controls } & \multicolumn{4}{|c|}{ Treatments } \\
\hline & & T1 & $\mathrm{T} 2$ & T3 & T4 \\
\hline \multicolumn{6}{|l|}{ First phase $(n=20)$} \\
\hline Initial body weight & $1.72 \pm 0.09^{a}$ & $1.74 \pm 0.08^{\mathrm{a}}$ & $1.75 \pm 0.10^{\mathrm{a}}$ & $1.73 \pm 0.08^{\mathrm{a}}$ & $1.73 \pm 0.09^{a}$ \\
\hline Final body weight & $3.13 \pm 0.15^{\mathrm{a}}$ & $1.41 \pm 0.06^{d}$ & $1.75 \pm 0.07^{d}$ & $2.15 \pm 0.14^{c}$ & $2.70 \pm 0.18^{b}$ \\
\hline \multicolumn{6}{|l|}{ Second phase $(n=16)$} \\
\hline Initial body weight & $3.13 \pm 0.03^{a}$ & $1.40 \pm 0.21^{d}$ & $1.75 \pm 0.19^{d}$ & $2.14 \pm 0.29^{c}$ & $2.70 \pm 0.07^{b}$ \\
\hline Final body weight & $4.33 \pm 0.27^{a}$ & $2.47 \pm 0.24^{c}$ & $3.32 \pm 0.25^{b}$ & $3.74 \pm 0.25^{\mathrm{ab}}$ & $4.41 \pm 0.31^{\mathrm{a}}$ \\
\hline Feed conversion ratio (FCR) & $2.10 \pm 0.04^{a}$ & $1.98 \pm 0.10^{\mathrm{a}}$ & $1.74 \pm 0.04^{b}$ & $1.67 \pm 0.01^{b}$ & $1.69 \pm 0.05^{b}$ \\
\hline
\end{tabular}

restricted groups (T1 and T2) obtained higher FCR (2.1 \pm 0.04 and $1.98 \pm 0.10)$ (Table 3).

Percentage body compositions of different treatment groups at end of second phase of experiment are shown in Table 4. There was no significant difference in ash and total carbohydrate content among various treatment groups. Severely restricted groups ( $\mathrm{T} 1$ and T2) recorded significantly lower content of crude protein and crude lipid. But there was significantly higher moisture content in severely restricted groups ( $\mathrm{T} 1$ and T2) compared to others.

IGF-I and IGF2a gene expressions were observed as down regulated in all the treatment groups at the end of first phase (Figure 1). IGF-I gene expression was significantly lower in treatment group T1 (10\% satiation fed) followed by T2 compared to control. But, after second phase, there was no significant difference in IGFI gene expression levels in T2, T3 and T4 (25\%, 50\% and $75 \%$ satiation fed respectively).

IGF-2a gene expression level was significantly similar in control and T1 ( $10 \%$ satiation fed) at end of first phase. However, after second phase, all the treatment groups obtained drastic increase in IGF-2a gene expression level and the highest expression was observed in T3 (50\% satiation fed) and lowest was in T1 (10\% satiation fed).

\section{Discussions}

Inducing compensatory growth in fishes has the possibility of improving fish growth, feed utilization and reduced feed wastage in modern aquaculture (Johnston, Ritar and Thomas, 2004; Berrill, Porter and Bromage, 2006). The rate of fish growth depends on feeding regimes and environmental factors (Peres and Olive-Teles, 2005). In the present study, at the end of first phase, all the treatment groups recorded lower weight compared to control as supported by Peres and Olive-Teles, (2005), who reported that growth rate is linearly correlated with food intake. In the present study, severe restriction at $10 \%$ satiation had caused lowering of body weight from weight at stocking. While, moderately restricted $(50-75 \%$ satiation fed) groups registered an increase in body weight after first phase, which was significantly lower than control.

In the present study, at the end of second phase, moderately restricted groups $(50 \%$ and $75 \%$ satiation fed) attained significantly similar body weight as of control (satiation fed). The result indicates that the feeding can be efficiently restricted upto $50 \%$ of satiation for a period of 6 weeks to trigger compensatory growth in common carp fry. On the other hand, severe restrictions will lead to partial compensation as indicated by lower body weight obtained by $\mathrm{T} 1$ and $\mathrm{T} 2$ ( $10 \%$ and $25 \%$ satiation fed). Tian and Qin, (2004) observed that a moderate feed restriction ( $50 \%$ or $75 \%$ of satiation) for 2 weeks could fully compensate, while $0 \%$ or $25 \%$ satiation for 2 weeks did not help full compensation in Barramundi (Latescalcarifer). Srijila, Rani, Babu\& Tiwari, (2014) also observed that moderate feed restriction $(50 \%-75 \%)$ for 
Table 4. Effect of ration restriction ( $6^{\text {th }}$ week) and re-alimentation ( $8^{\text {th }}$ week) on body composition of $C$. carpio after $14^{\text {th }}$ week (wet weight basis)

\begin{tabular}{lccccc}
\hline Treatment & Moisture (\%) & Crude protein (\%) & Crude lipid (\%) & Ash (\%) & Total carbohydrate (\%) \\
\hline C & $71.00 \pm 0.80^{\mathrm{b}}$ & $17.47 \pm 0.51^{\mathrm{a}}$ & $3.22 \pm 0.23^{\mathrm{a}}$ & $2.61 \pm 0.12^{\mathrm{a}}$ & $5.51 \pm 0.17^{\mathrm{a}}$ \\
T1 & $74.04 \pm 0.40^{\mathrm{a}}$ & $15.26 \pm 0.39^{\mathrm{b}}$ & $2.49 \pm 0.08^{\mathrm{c}}$ & $2.76 \pm 0.13^{\mathrm{a}}$ & $6.06 \pm 0.17^{\mathrm{a}}$ \\
T2 & $72.86 \pm 0.15^{\mathrm{ab}}$ & $15.65 \pm 0.17^{\mathrm{b}}$ & $2.66 \pm 0.05^{\mathrm{bc}}$ & $2.71 \pm 0.06^{\mathrm{a}}$ & $6.01 \pm 0.13^{\mathrm{a}}$ \\
T3 & $71.42 \pm 0.76^{\mathrm{b}}$ & $17.01 \pm 0.38^{\mathrm{a}}$ & $2.99 \pm 0.10^{\mathrm{ab}}$ & $2.57 \pm 0.15^{\mathrm{a}}$ & $6.00 \pm 0.29^{\mathrm{a}}$ \\
T4 & $71.22 \pm 0.65^{\mathrm{b}}$ & $17.48 \pm 0.32^{\mathrm{a}}$ & $3.24 \pm 0.03^{\mathrm{a}}$ & $2.56 \pm 0.09^{\mathrm{a}}$ & $5.48 \pm 0.22^{\mathrm{a}}$ \\
\hline
\end{tabular}

Means with different superscripts in the same column are significantly different among treatment groups $(\mathrm{P}<0.05)$. Data expressed as Mean \pm SE, $(n=4)$. Values in percentages were arsine transformed and analysed. First phase, control: satiation level fed T1: $10 \%$ of satiation fed, T2: $25 \%$ of satiation fed, T3: $50 \%$ of satiation fed, T4: $75 \%$ of satiation fed. Second phase, all the treatment groups fed up to the satiation levels during realimentation phase $\left(8^{\text {th }}\right.$ week).
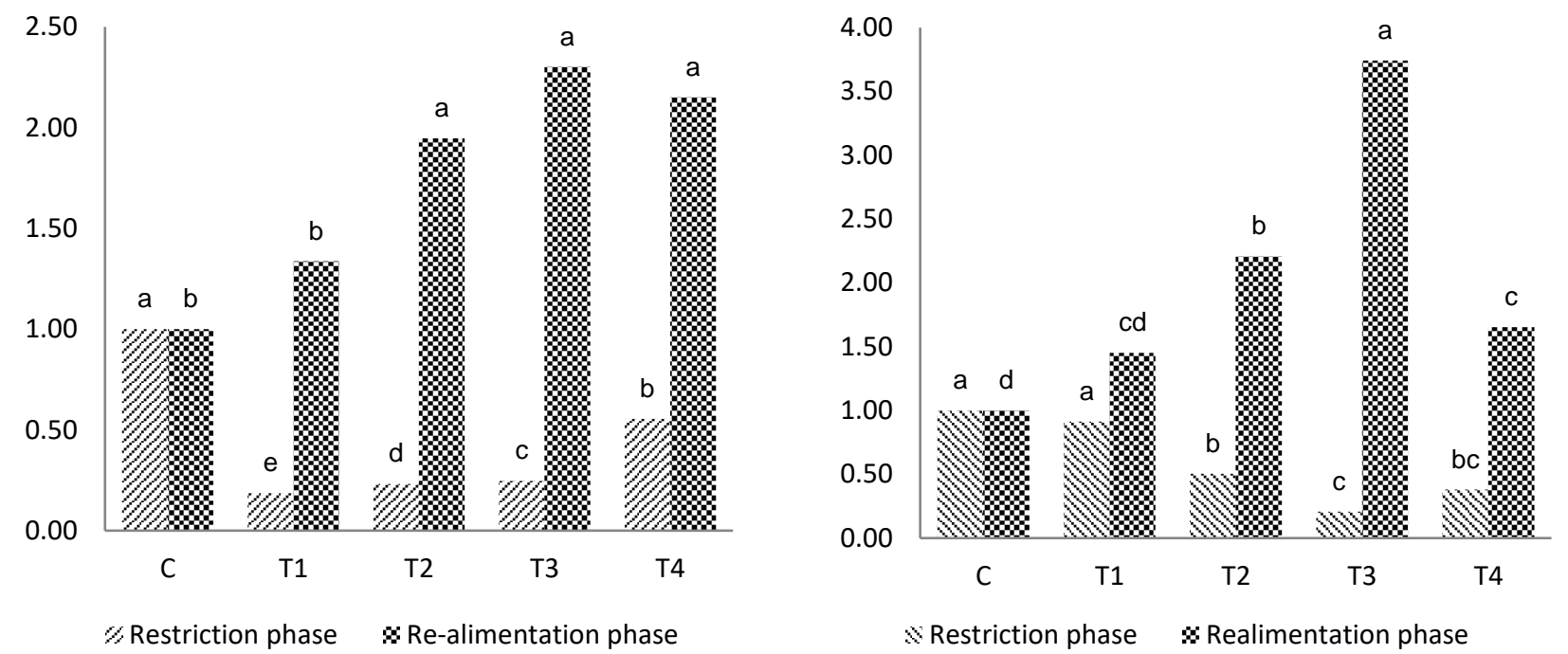

Figure 1. Relative IGF-I (left) and IGF2a (right) gene expression by Real Time PCR during ration restriction (6 $6^{\text {th }}$ week) and realimentation phases ( $8^{\text {th }}$ week). The different superscripts in the same column are significant difference in mean values among different treatment groups $(P<0.05)$. Date expressed as mean $\pm S . E,(n=4)$. Control fish fed to satiation levels though out the experiment, $\mathrm{T} 1, \mathrm{~T} 2, \mathrm{~T} 3$ and $\mathrm{T} 4$ treatment groups fed at the rate of $10 \%, 25 \% 50 \%$ and $75 \%$ of satiation, respectively during ration restriction ( $6^{\text {th }}$ week) and all the treatment groups fed up to the satiation levels during re-alimentation phase $\left(8^{\text {th }}\right.$ week).

a period of 6 weeks and realimentation helped to compensate the retarded growth in Labeorohita.

In the present study, improved FCR of $1.67 \pm 0.01$ and $1.69 \pm 0.05$ was registered in $50 \%$ and $75 \%$ of satiation fed group respectively. Moderate ration restriction led to improved FCR in L. rohita (Srijilaet al., 2014) and also there are reports on improved feed efficiency ratio in fishes which undergone compensatory growth (Van Dijk, Staaks and Hardewig, 2002). These findings can be attributed to increased efficiency in feed utilisation during growth compensation. Manipulating feeding regimes had improved feed efficiency of different fish species, reduced feed consumption and showed better growth effects (Johnston et al., 2004; Khan, Ahmed and Abidi, 2004; Berrillet al., 2006).

Body composition of fish is often used as an indicator of nutritional quality of the fish. In the present study, moisture, crude lipid, ash and total carbohydrate content were significantly affected by ration restriction at $10 \%$ and $25 \%$ satiation level. Restricted feeding at moderate level (50-75\% satiation fed) did not alter the body composition of the fishes as indicated by the present results. Hence it can be concluded that moderate restriction for a short term (6 weeks) will not alter the nutritional quality of fish flesh. Fasting or ration restriction generally leads to a reduction in crude lipid, crude protein content and increase in the moisture, ash and total carbohydrate content of fish tissues (Weatherley and Gill, 1987; Collins and Anderson, 1995). But according to the current results, the severe restriction for short term led to reduction in crude protein and crude lipid levels in the tissue.

Insulin-like growth factor I (IGF-I) is one of the chief anabolic agent responsible for tissue growth (Duan, 1998; Thissen, Underwood and Ketelslegers, 1999). In the present study, at the end of 1st phase, IGF-I gene expression had declined significantly with degree of restriction. But, those treatment groups restricted from $25-75 \%$ of satiation indicated significantly higher IGF-I gene expression after second phase in comparison to 
others. Reductions in liver IGF-I gene expression level due to fasting and subsequent recovery during refeeding have been observed in many fishes (Gabillard, Kamangar and Montserrat, 2006a; Montserrat, Gabillard, Capilla, Navarro and Gutierrez, 2007a; Fox, Breves, Pierce, Hirano, Grau, 2010). It was previously reported that IGF-I gene expression levels decline in liver, after 2 to 4 weeks of fasting (Uchida et al.,2003; Fox, Riley, Hirano and Grau, 2006). Enhanced liver IGF-I expression can be related to the growth compensation in fishes and it varies with degree of feed restriction. Growth hormone acts directly on target tissue by stimulating mitosis and other energy metabolism and indirectly by initiating the production and release of IGF$I$ in the liver (Duan 1997; Wood et al.,2005). The reduction and recovery of IGF-I gene expression levels during ration restriction and re-alimentation in the present study indicated the importance of nutritional axis for regulation of growth in fish. Further, IGF genes play an important role in somatic growth, reproduction, osmoregulation and immune system (McCormick, 1996; Maestro, Mendez, Parrizas and Gutierrez, 1997; Norbeck, Kittilson and Sheridan, 2007; Yada, 2007). Similarly, Picha, Turano, Tipsmark and Borski, (2008b) reported that a decrease in plasma IGF-I is driven by a decrease in liver IGF-I production capacity due to a fasting-induced reduction in liver size. Therefore, a minimum intake of essential nutrients may be necessary to maintain liver IGF-I gene expression.

The present study indicated an elevated expression of IGF-2a gene in control compared to all the treatment groups which were fed restricted ration. But after re-feeding, all the feed restricted groups indicated higher expression of IGF-2a gene compared to control, of which $50 \%$ satiation fed groups recorded the highest expression. The highest IGF-2a gene expression obtained in $50 \%$ satiation fed group can be correlated with the higher rate of compensatory growth as evidenced in final weight gain. The present study supports the earlier finding (Yuan et al., 2011), which reported a reduced IGF-2a gene expression level in grass carp during starvation ( 6 days) and rebounding after refeeding (6 days). Similarly, there is clear evidence that insulin-like growth factor II (IGF-II) is related to local paracrine/autocrine regulation of muscle tissue growth in teleost fishes (Vong, Chan and Cheng, 2003; Hevrøyet al. 2007). The present study emphasised nutritional effect on the IGF-I and IGF-2a gene expression levels in the liver of Cyprinus carpio. In other teleost fish species, the liver IGF-2 gene were also affected by nutritional status (Gabillardet al., 2006; Ayson, de Jesus-Ayson and Takemura, 2007; Terova, et al., 2007).

\section{Conclusion}

Compensatory growth after moderate ration restriction improves growth, feed utilization and feed conversion without affecting nutritional quality of the flesh. In Aquaculture management inducing compensatory growth improve the growth rates, feed utilisation and reduce feed wastage and the feed cost in the culture system. There is up regulation of expression of genes such as IGF-I and IGF-2a in fishes compensating for their restricted growth.

\section{Acknowledgments}

We wish to acknowledgement our sincere gratitude to the Indian Council of agricultural Research (ICAR) and The Director, Central Institute of Fisheries Education, Mumbai, India for granting institutional fellowship for the successful completion of this piece of research work. We also acknowledge the facilities provided at Wet laboratory (Aquaculture), Fish Genetics and Biotechnology Laboratory of CIFE, Mumbai to carry out this research work successfully.

\section{References}

Abdel-Hakim, N.F, Abo State, H.A, Al-Azab\& El-Kholy, Kh. F, (2009). Effect of feeding regimes on growth performance of juvenile hybrid tilapia (Oreochromis niloticusx Oreochromis aureus). "World Journal of Agricultural Sciences," 5(1), 49-54.

Ali, M., Nicieza, A. \& Wootton, R.J, (2003). Compensatory growth in fishes: a response to growth depression. "Fish and Fisheries," 4(2), 147-190. https://dx.doi.org/10.1046/j.1467- 2979.2003.00120.x

AOAC, (1995). Official methods of analysis of the Association of Official Analytical Chemists, 16th edn. Association of Official Analytical Chemists, Arlington.

Ayson, F. G., de Jesus-Ayson, E. G. T. \&Takemura, A, (2007). mRNA expression patterns for GH, PRL, SL, IGF-I and IGFII during altered feeding status in rabbitfish, Siganusguttatus. "General and Comparative Endocrinology,"150(2), 196-204. https://dx.doi.org/10.1016/j.ygcen.2006.08.001

Berrill, I. K., Porter, M. J. R. \&Bromage, N. R, (2006). The effects of daily ration on growth and smoltification in $0+$ and $1+$ Atlantic salmon (Salmo salar) parr. "Aquaculture" 257(14), 470-481.

https://dx.doi.org/10.1016/j.aquaculture.2006.03.023

Collins, A. L. \& Anderson, T. A, (1995). The regulation of endogenous energy stores during starvation and refeeding in the somatic tissues of the golden perch. "Journal of Fish Biology,"47(6), 1004-1015.

Duan, C., 1997. The insulin-like growth factor system and its biological actions in fish. "Integrative and Comparative Biology,"37(6), 491-503.

Duan, C. M, (1998). Nutritional and developmental regulation of insulin-like growth factors in fish. "The Journal of Nutrition,"128(2), 306S-314S.

https://doi.org/10.1093/jn/128.2.306S

Foss, A., Imsland, A.K., Vikingstad, E., Stefansson, S.O., Norberg, B., Pedersen, S., Sandvik, T., \& Roth, B, (2009). Compensatory growth in Atlantic halibut: effect of starvation and subsequent feeding on growth, maturation, feed utilization and flesh quality. "Aquaculture,"290(3-4),304310.https://dx.doi.org/10.1016/j.aquaculture.2009.02. 021 
Fox, B.K., Breves, J.P., Pierce, A. L., Hirano T. \& Grau, E. G, (2010). Tissue-specific regulation of the growth hormone/insulin-like growth factor axis during fasting and re-feeding: Importance of muscle expression of IGFI and IGF-II mRNA in the tilapia. "General and Comparative Endocrinology," 166(3), 573-580. https://dx.doi.org/10.1016/j.ygcen.2009.11.012

Fox, B.K., Riley, L.G., Hirano, T. \& Grau, E.G, (2006). Effects of fasting on growth hormone, growth hormone receptor, and insulin-like growth factor-I axis in seawater acclimated tilapia, Oreochromis mossambicus. "General and Comparative Endocrinology,"148(3),340-347 https://dx.doi.org/10.1016/j.ygcen.2006.04.007

Gabillard, J. C., Kamangar, B. B. \& Montserrat, N, (2006a). Coordinated regulation of the GH/IGF system genes during refeeding in rainbow trout (Oncorhynchus mykiss). "The Journal of Endocrinology," 191(1), 15-24. https://dx.doi.org/10.1677/joe.1.06869

Hayward, R. S., Noltie, D.B., \& Wang, N, (1997). Use of compensatory growth to double hybrid sunfish growth rates. "Transactions of the American Fisheries Society,"126(2),

316-322. https://dx.doi.org/10.1577/T05-003.1

Hevrøy, E. M., El-Mowafi, A., Taylor, R., Olsvik P. A., Norberg, B., \&Espe, M, (2007). Lysine intake affects gene expression of anabolic hormones in Atlantic salmon (Salmo salar). "General and Comparative Endocrinology,"152(1), $39-46$. https://dx.doi.org/10.1007/s10695-010-9434-3

Jobling, $M$ (2009). Are compensatory growth and catch-up growth two sides of the same coin? "Aquaculture International,"18(4), https://dx.doi.org/10.1007/s10499-009-9260-8

Jobling, $M$, (2012). Fish in aquaculture environments. In: Aquaculture and Behaviour, Wiley-Blackwell, 36-64.

Jobling, M., Meløy, O. H., Dos Santos, J. \& Christiansen, B, (1994). The compensatory growth response of the Atlantic cod: effects of nutritional history. "Aquaculture International". 2, 75-90.

Johnston, I. A, (2001b). Genetic and environmental determinants. In: Johnston, L.A. (Ed.), Muscle Development and Growth. Fish Physiology Series, vol.18. Academi c Press, San Diego, 141-186.

Johnston, D. J., Ritar, A. J., \& Thomas, C. W, (2004). Digestive enzyme profile reveal digestive capacity and potential energy sources in fed and starved spiny lobster (Jasusedwardsii) phyllosoma larvae. "Comparative Biochemistry andPhysiology Part B, Biochemistry \& Molecular Biology". 138(2), 137-144. https://dx.doi.org/10.1016/j.cbpc.2004.02.013

Khan, M. A., Ahmed, I., \&Abidi, S. F, (2004). Effect of ration size on growth, conversion efficiency and body composition of fingerling mrigal, Cirrhinusmrigala(Hamilton). "Aquaculture Nutrition," 10(1), 47-53. https://dx.doi.org/10.1046/j.1365-2095.2003.00279.x
Maestro, M.A., Mendez, E., Parrizas, M., \& Gutierrez, J, (1997). Characterization of insulin and insulin-like growth factorI ovarian receptors during the reproductive cycle of carp (Cyprinus carpio). "Biology of Reproduction," 56(5), 1126-32.

McCormick S.D, (1996). Effects of growth hormone and insulinlike growth factor I on salinity tolerance and gill Nap, KpATPase in Atlantic salmon (Salmo salar): interaction with cortisol. "General and Comparative Endocrinology," 101, 3-11.

Montserrat, N., Gabillard, J. C., Capilla, E., Navarro, M. I., \& Gutierrez, J, (2007a). Role of insulin, insulin-like growth factors, and muscle regulatory factors in the compensatory growth of the trout (Oncorhynchus mykiss). "General and Comparative Endocrinology," 150(3), $462-472$ https://dx.doi.org//10.1016/j.gcen.2006.11.009

Norbeck, L. A., Kittilson, J. D., \& Sheridan, M. A, (2007). Resolving the growth promoting and metabolic effects of growth hormone: differential regulation of GH- IGF-I system components. "General and Comparative Endocrinology," 151(3), 332-341. https://dx.doi.org//10.1016/j.gcen.2007.01.039

Peres, H., \& Oliva-Teles, A, (2005). Protein and energy metabolism of European seabass (Dicentrarchuslabrax) juveniles and estimation of maintenance requirements. "Fish Physiology and Biochemistry"31(1), 23-31. https://dx.doi.org/10.1007/s10695-005-4586-2

Peterson, B. C., \&Waldbieser, G. C., (2009). Effects of fasting on IGF-I, IGF-II, and IGF-binding protein mRNA concentrations in channel catfish (Ictalurus punctatus). "Domestic Animal Endocrinology," 37(2), 7483.

https://dx.doi.org/10.1016/j.domaniend.2009.03.004

Picha, M.E., Turano, M. J., Tipsmark, C. K., \& Borski, R. J, (2008b). Regulation of endocrine and paracrine sources of IGFs and Ghreceptor during compensatory growth in hybrid striped bass (Moronechrysops X Moronesaxatilis). "TheJournal of Endocrinology"199(1), 81-94. https://dx.doi.org/10.1677/JOE-07-0649

Robb, D, (2008). Welfare of fish at harvest. In: Fish welfare, 1st edn. (Ed. by E. J. Branson), p. 217-242. Oxford: Blackwell Publishing Ltd.

Sambrook, J., \& Russell, D. W, (2001). Molecular cloning: A laboratory manual, 3rd edition. Cold Spring Harbour Laboratory Press, Cold Spring Harbour, New York. 578.

Srijila, C. K., Rani B. A. M., Babu, P.G., \& Tiwari, V. K, (2014). Ration restriction, compensatory growth and pituitary growth hormone gene expression in Labeorohita. Aquaculture International. 22(2), 1703-1710. https://dx.doi.org/10.1007/s10499-014-9775-5

Su, J., Zhu, Z., \& Wang, Y, (2008). Molecular cloning and characterization and expression analysis of the PKz gene in rare minnow (Gobiiocyprisrarus). "Fish \& shellfish Immunology," 25, 106-113. https://dx.doi.org/10.1016/j.fsi.2008.03.006 